\title{
ДОСВІД ВПРОВАДЖЕННЯ СИСТЕМИ НЕПЕРЕРВНОЇ ОСВІТИ ПРОВІЗОРІВ 3 ФАРМАКОЕКОНОМІКИ
}

\author{
О. М. Заліська, Б. Л. Парновський, М. В. Слабий, І. Г. Мудрак* \\ Львівський національний медичний університет імені Данила Галицького, \\ *Вінницький національний медичний університет імені М. І. Пирогова

\section{EXPERIENCE OF UNINTERRUPTED EDUCATION SYSTEM OF PHAMACEUTISTS ON PHARMACOECONOMICS} \\ O. M. Zaliska, B. L. Parnovskyi, M. V. Slabyi, I. H. Mudrak* \\ Lviv National Medical University by Danylo Halytskyi, \\ *Vinnytsia National Medical University by M. I. Pyrohov
}

\begin{abstract}
У статті представлено напрями впровадження системи неперервної освіти провізорів при вивченні фармакоекономіки з використанням Інтернет-ресурсів. Підготовлено навчальні програми, навчальні посібники з фармакоекономіки для післядипломної освіти провізорів.
\end{abstract}

The paper presents the directions of implementation of continuous education system of pharmaceutists in the study of pharmacoeconomics using Internet resources. There have been prepared curricula, textbooks on pharmacoeconomics for postgraduate education of pharmaceutists.

Вступ. ВООЗ та Міжнародною фармацевтичною федерацією (FIP) розроблено стратегічний план 3 глобалізації фармацевтичної освіти, розвитку відповідних модулів навчання провізора як експерта у сучасній охороні здоров'я, який забезпечує лікарів, керівників охорони здоров'я доказовою інформацією про ефективність витрат на медичні технології та підвищує якість фармацевтичної допомоги [18, 19]. Аналіз навчальних планів фармацевтичних факультетів Європи показав, що дисципліна “Фармакоекономіка" включена у навчальні плани бакалавра, магістра фармації, доктора філософії, зокрема у Гарварді - 2,5 кредити; у Йоркському університеті - 2,0 кредити.

Проблематиці стратегії євроінтеграційного реформування вищої медичної освіти присвячені праці провідних вчених, в яких подано Програму третього рівня медичної освіти як безперервного професійного розвитку лікарів [15]. Нами було обгрунтовано концепцію системи непереревної освіти провізорів на прикладі вивчення дисципліни “Фармакоекономіка”, оволодіння якою є професійно перспективним (Медична освіта.-2008) [13]. Відсутні дані про функціонуючі системи неперервного навчання провізорів упродовж професійного життя 3 використанням можливостей дистанційного навчання. Нашою метою було впровадити систему навчання провізорів 3 фармакоекономіки з використанням дистанційної підготовки за допомогою Інтернет-ресурсів.

Основна частина. 31999 року на кафедрі організації і економіки фармації та технології ліків факультету післядипломної освіти ЛНМУ імені Данила Галицького вперше в Україні було започатковане викладання дисципліни “Фармакоекономіка" для провізорів-інтернів та слухачів курсів. У 2000 році нами були видані перші навчальні посібники "Фармакоекономіка. У 2 ч.", які були затверджені Центральною методичною комісією університету, оскільки будь-які навчально-методичні матеріали були повністю відсутні в Україні [6]. Для ознайомлення практичних провізорів були опубліковані статті з проблематики фармакоекономіки у фахових журналах [5, 9, 10].

У 2001 році з урахуванням накопиченого досвіду, аналізу навчальних планів університетів Свропи, результатів апробації навчальних посібників були ство-

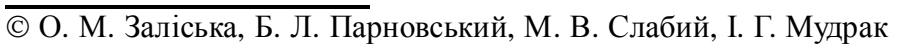


рені перша типова навчальна програма “Фармакоекономіка" та був виданий навчальний посібник “Основи фармакоекономіки” (2002) [3]. Навчальнометодичне забезпечення 3 фармакоекономіки було впроваджено у підготовку провізорів в 11 вищих навчальних медичних і фармацевтичних закладах України, зокрема у Харкові, Києві, Львові, Тернополі, Одесі, Вінниці, Івано-Франківську, Чернівцях, Києві і використовується на даний час [4].

Слід відзначити, що в інших вищих навчальних закладах були видані навчальні посібники з фармакоекономіки $[10,15]$.

За результатами апробації навчального посібника “Основи фармакоекономіки” з урахуванням тенденцій розвитку фармакоекономіки у світі, нами видано перший в Україні підручник “Фармакоекономіка” (2007), підготовлений за вимогами кредитно-модульної системи навчання студентів [8].

З урахуванням накопиченого нами досвіду та відповідно до типової навчальної програми передатестаційних циклів зі спеціальності “Організація та управління фармацією”, яка включає тематику з фармакоекономіки, було видано перший навчальний посібник “Фармакоекономіка" для післядипломної освіти провізорівінтернів та слухачів факультетів післядипломної освіти, який затверджений МОЗ України (2007) [7].

На нашій кафедрі під час передатестаційних циклів провізори послідовно ознайомлюються 3 історією розвитку фармакоекономіки, ії об'єктами, предметом досліджень, зв' язками з іншими фармацевтичними, медичними науками. Детально вивчають терміни за вимогами Міжнародного товариства фармакоекономічних досліджень (ISPOR) на основі офіційного видання “Словник термінів ISPOR”. Знайомляться 3 методами фармакоекономічного аналізу лікарських засобів “вартість-ефективність”, "мінімізація вартості”, “вартість-користь”, “вартість-вигода”, “вартість захворювання” та використання їх результатів для оптимізації фармакотерапії. Значна увага приділяється вивченню принципів формулярної системи лікарського забезпечення. Це особливо актуально відповідно до положень Концепції розвитку фармацевтичного сектора на 2011-2020 рр. яка передбачає застосування фармакоекономіки та формулярної системи в Україні.

Слід відзначити, що проводиться диференціація викладання навчального матеріалу з фармакоекономіки: слухачам зі спеціальності “Організація та управління фармацією” більша увага приділяється питанням з організації формулярного забезпечення хворих, визначення потреби в препаратах. Провізори зі спеціальності “Загальна фармація” одержують більше інформації про фармакоекономічні аспекти фармакотерапії поширених захворювань для подальшого застосування знань 3 метою надання обгрунтованих рекомендацій хворому щодо ефективного та економічно вигідного лікарського засобу.

На практичних та семінарських заняттях провізори оволодівають вміннями фармакоекономічної оцінки лікарських засобів, обчислюють коефіцієнти “витратиефективність” препаратів для лікування поширених захворювань.

За рішенням Міжнародного товариства фармакоекономічних досліджень (ISPOR) (2008), яке координує розвиток практичних та освітніх напрямів фармакоекономіки у провідних країнах, було створено Український відділ Міжнародного товариства фармакоекономічних досліджень (USPOR). Для діяльності відкрито україномовну веб-сторінку www.uspor.org, на якій представлені інформаційні матеріали про діяльність цієї міжнародної організації та навчальні матеріали, наукові статті про теоретичні напрями та результати фармакоекономічних досліджень в Україні.

32008 року на кафедрі систематично проводяться науково-практичні конференції для провізорів на тему “Фармакоекономіка в Україні”, на яких розглядаються актуальні питання розвитку фармакоекономічних досліджень у європейських країнах, використання їх результатів при відшкодуванні вартості ліків за даними європейських конгресів Міжнародного товариства фармакоекономічних досліджень, а також напрями впровадження фармакоекономіки і формулярної системи в Україні.

Для реалізації вимог наказу МОЗ України № 484 від 07.07.2009 р. “Про затвердження змін до Положення про проведення іспитів на передатестаційних циклах" і забезпечення засад неперервної освіти провізорів на кафедрі систематично проводяться науковопрактичні конференціі, які сприяють удосконаленню знань аптечних працівників і надають бали для отримання кваліфікаційної категорії. Так, у квітні 2010 року на кафедрі організації і економіки фармації та технології ліків ФПДО ЛНМУ ім. Данила Галицького відбулась 5-та конференція “Фармакоекономіка і формулярна система в Україні”, проведена вченими кафедри та за участю близько 100 завідувачів аптек, спеціалістів з організації та управління фармацією, провізорів загальної фармації Львівської області та Львівської обласної аптечної корпорації [2].

Для функціонування системи неперервної освіти 3 фармакоекономіки нами було створено і затверджено навчальний план та навчальну програму для провізо- 
рів з урахуванням вимог наказу МОЗ України № 484 від 07.07.2009 р. “ЗЗміни до Положення про проведення іспитів на передатестаційних циклах, затвердженого наказом МО3 України № 73 від 18.05.94” $[1,12,13]$. У цих навчально-методичних матеріалах структуровано за модулями теми 3 фармакоекономіки для самостійного вивчення провізорами.

Нами впроваджено систему неперервної освіти 3 фармакоекономіки провізорів у період між циклами. Після проходження атестації провізори продовжують використовувати навчальні матеріали з термінології, теорії розвитку фармакоекономіки з веб-сторінки www.uspor.org. Якщо відсутній доступ до Інтернету, то ознайомлюються з публікаціями у фахових журналах “Фармацевтичний журнал”, “Клінічна фармація”, “Фармацевт-Практик”, “Провізор” та оволодівають термінологією науки, проводять моніторинг сучасних напрямів діяльності ISPOR. При цьому провізори самостійно поглиблюють свої знання 3 питань термінології Міжнародного словника термінів ISPOR BOOK of Terms, який представлено на Iнтернет-сторінці. Також для підвищення рівня інформованості про фармакоекономіку для практичних провізорів можливою є участь у конференціях, які проводяться на кафедрі організації і економіки фармації та технології ліків ЛНМУ ім. Данила Галицького щорічно. Так, у квітні 2010 року була проведена 5-та науково-практична конференція “Фармакоекономіка в Україні”, в якій брали участь більше 100 практичних провізорів.

\section{Лiтература}

1. Безперервна професійна освіта 3 фармакоекономіки для провізорів зі спеціальностей “Організація та управління фармацією”, “Загальна фармація” між передатестаційними циклами : методичні рекомендації / О. М. Заліська, М. В. Слабий, Б. Л. Парновський, І. Г. Мудрак. - Львів : ЛНМУ імені Данила Галицького, 2009. - 18 с.

2. Дедишина Л. Навчатися - кожного дня // ФармацевтПрактик. -2010. - №6. - С.19-21.

3. Заліська О. М. Основи фармакоекономіки: навч. пос./ О. М. Заліська; заред. Б. Л. Парновського.-Львів, 2002.-364 с.

4. Заліська О. М. Теоретичні основи та практичне використання фармакоекономіки в Україні : автореф. дис.... канд. фарм. наук : $15.00 .01 /$ Технологія ліків та організація фармацевтичної справи / О. М. Заліська. - Львів, 2004. - 33 с.

5. Заліська О. М. Уніфіковані стандарти медичних технологій як база фармакоекономічних досліджень в Україні / О. М. Заліська, Б. Л. Парновський, М. В. Слабий // Ліки України. - 2000. - № 9. - С.13-14.

6. Заліська О. М. Фармакоекономіка : навч. пос. / О. М. Заліська ; за ред. Б. Л. Парновського. - Львів : Простір-М, 2000. - Ч. 1. -64 c.; Ч. 2. -71 c.
У період між циклами провізори ознайомлюються 3 методами фармакоекономічного аналізу “мінімізація вартості” та "вартість-ефективність”, використовуючи журнали: “Аптека Галицька”, “ФармацевтПрактик”, “Фармацевтичний журнал”, “Провізор” тощо та матеріали на веб-сторінці.

Слід відзначити, що лекції та семінарські заняття 3 фармакоекономіки за 2000-2011 навчальні роки було проведено для більш як 11000 провізорів і провізорівінтернів Волинської, Львівської, Івано-Франківської, Закарпатської, Рівненської, Тернопільської, Хмельницької, Чернівецької областей.

Висновок. Реформування вищої фармацевтичної освіти відповідно вимог Болонської декларації повинно сприяти підготовці провізорів з сучасних дисциплін, оволодіння новітніми технологіями здобуття нових знань при використанні кредитно-модульної системи навчання. Впровадження системи неперервної освіти провізорів з використанням дистанційного навчання свідчить про актуальність і доцільність оволодіння навичками фармакоекономічного аналізу у системі післядипломної підготовки провізорів.

Сучасний провізор має вільно орієнтуватися у науковій інформації, вміти відрізняти матеріали сумнівної цінності від достовірних і корисних даних, які служать основою прийняття управлінських рішень у системі охорони здоров'я та при допомозі індивідуальному хворому.

7. Заліська О. М. Фармакоекономіка : навч. пос. / О. М. Заліська ; за ред. Б. Л. Парновського. - Львів : Афіша, 2007. - $400 \mathrm{c}$.

8. Заліська О. М. Фармакоекономіка : підручник / О. М. Заліська; за ред. Б. Л. Парновського. -Львів : Афіша, 2007.- 376с.

9. Заліська О. М. Фармакоекономіка: теорія і практика / О. М. Заліська // Фармац. журн. - 2000. - № 2. - С.10-16.

10. Заліська О. М. Теоретичні основи фармакоекономіки та їх використання в урологічній практиці / О. М. Заліська, Б. Л. Парновський // Клінічна фармація. - 2000. - Т.4, №4. - С.40-44.

11. Мостовий Ю. М. Фармакоепідеміологічні та фармакоекономічні дослідження у медицині: навч. пос. / Ю. М. Мостовий, І. Г. Томашкевич, Т. В. КонстатиновичЧічірельо. - Вінниця, 2003. - 79 с.

12. Навчальна програма безперервної освіти з фармакоекономіки для провізорів зі спеціальностей “Організація та управління фармацією”, “Загальна фармація” між передатестаційними циклами / О. М. Заліська, М. В. Слабий, Б. Л. Парновський, І. Г. Мудрак. - Львів : ЛНМУ імені Данила Галицького, 2009. - 19 с. 